\title{
PERANAN APOTEKER DALAM PEMBERIAN SWAMEDIKASI PADA PASIEN BPJS
}

\author{
Yulia Pratiwi ${ }^{1}$, Annis Rahmawaty ${ }^{2}$, Ricka Islamiyati ${ }^{3}$ \\ 1,2,3 STIKES Cendekia Utama Kudus \\ annis.rahmawaty@yahoo.com
}

\begin{abstract}
ABSTRAK
Swamedikasi merupakan upaya seseorang untuk mengobati gejala penyakit tanpa melakukan konsultasi terlebih dahulu dengan dokter. Pemilihan dan penggunaan obat tersebut ditujukan untuk mengatasi penyakit dan gejala penyakit ringan. Besarnya biaya kesehatan di Indonesia yang tergolong mahal sebagian diantaranya telah dapat diatasi dengan adanya jaminan kesehatan seperti BPJS. Apoteker mempunyai peranan yang sangat besar untuk menjamin bahwa pasien menerima obat dan pengobatan dengan baik, aman, dan efektif sesuai dengan tujuan terapi. Kegiatan pengabdian masyarakat ini bertujuan secara umum untuk mengubah pola pikir dan cara pandang masyarakat untuk dapat menyikapi secara tepat tentang informasi mengenai penyakit-penyakit yang dapat diobati sendiri oleh pasien. Hasil penelitian ini didapatkan bahwa pengetahuan pasien BPJS setelah diberikan edukasi dan pengetahuan oleh apoteker tentang cara mengobati gejala penyakit dan cara melakukan swamedikasi terkait penggunaan obat yang baik dan benar dalam kehidupan sehari-hari sudah baik. Luaran penelitian ini antara lain adanya publikasi ilmiah di Jurnal Pengabdian Kesehatan CENDEKIA UTAMA ISSN 2614-3593 dan pengayaan bahan ajar Swamedikasi di Program Studi S1 Farmasi STIKES Cendekia Utama Kudus. telah sesuai target yang diharapkan.
\end{abstract}

Kata Kunci : Apoteker ; BPJS ; Swamedikasi

\begin{abstract}
Self-medication is an attempt by someone to treat the disease without consulting first with the doctor. The selection and use of these drugs is intended to treat diseases and minor illnesses. The high cost of health in Indonesia that must be classified as expensive must be overcome by health insurance such as BPJS. Pharmacists have a very big role in ensuring patients receive medication and care properly, safely, and effectively in accordance with the goals of therapy. Community service activities to change the mindset and perspective of the community to be able to respond to information about diseases that can be carried out by patients themselves. The results of this study were obtained from the knowledge of BPJS patients after being given education and knowledge by the pharmacist on how to research the disease and how to conduct selfmedication related to the use of good and right medicine in everyday life is good.
\end{abstract}


The outputs of this study Jurnal Pengabdian Kesehatan of CENDEKIA UTAMA ISSN 2614-3593 and enrichment of self-administered teaching materials in the STIKES Cendekia Utama Kudus Pharmacy Study Program. has met the expected target.

Keywords: Pharmacists; BPJS; Self-medication 


\section{PENDAHULUAN}

Cara seseorang mengobati segala keluhan pada diri sendiri dengan obat-obat yang sederhana yang dapat dibeli bebas di apotik atau toko obat atas inisiatif sendiri tanpa adanya nasehat dokter disebut dengan swamedikasi.[1] Peraturan Menteri Kesehatan (permenkes) mendefinisikan swamedikasi pada No.919/MENKES/PER/X/1993 sebagai upaya pengobatan yang dilakukan secara mandiri untuk mengobati gejala sakit atau penyakit tanpa berkonsultasi dengan dokter terlebih dahulu. Makna dari peraturan tersebut Pengobatan yang dimaksud dalam permenkes tersebut adalah upaya pasien untuk mencari tahu mengenai informasi obat yang sesuai dengan keluhan penyakitnya dengan bertanya pada apoteker. Pemberian informasi kepada pasien merupakan salah satu tugas dan peran penting apoteker dalam memberikan informasi obat yang objektif dan rasional pada pengobatan pasien.

Swamedikasi dapat dilakukan untuk keluhan dan kondisi penyakit yang ringan dan umum yang sering dialami masyarakat, seperti demam, nyeri, pusing, batuk, influenza, sakit maag, diare, serta keluhan pada penyakit kulit.[3] Pelaksanaan swamedikasi harus memenuhi kriteria penggunaan obat yang rasional, antara lain ketepatan pemilihan obat, ketepatan dosis obat, tidak adanya efek samping, tidak adanya kontraindikasi, tidak adanya interaksi obat, dan tidak adanya polifarmasi. Dalam praktiknya kesalahan penggunaan obat dalam swamedikasi ternyata masih banyak terjadi, terutama karena ketidaktepatan obat dan dosis obat. Apabila kesalahan tersebut terjadi terus-menerus dalam waktu yang lama akan dikhawatirkan dapat menimbulkan risiko pada kesehatan.[4]

Tujuan dari kegiatan pengabdian masyarakat ini secara umum dapat membentuk pola pikir dan cara pandang masyarakat untuk dapat menyikapi secara tepat tentang penggunaan obat terkait pengobatan yang dapat diobati sendiri oleh pasien tanpa konsultasi dengan dokter dimana peran serta apoteker dilakukan dengan memberikan penyuluhan 
kesehatan terkait penyakit yang dapat diobati sendiri oleh pasien, cara mendapatkan dan penggunaan obat yang baik dan benar.

\section{METODE PELAKSANAAN}

Penelitian pengabdian masyarakat ini berbentuk penyuluhan berupa pemberian edukasi kesehatan dalam bidang farmasi mengenai pentingnya mengetahui dan memahami penyakit-penyakit yang dapat diobati sendiri dan bagaimana manajemen pengobatan terkait permasalahan pasien dalam penggunaan obat. Penyuluhan edukasi ini secara umum diberikan kepada pasien BPJS di Fasilitas Kesehatan Tingkat I dr. Arief Adi Saputro yang diikuti sebanyak 32 orang. Kegiatan meliputi pengenalan tim pengabdian masyarakat, penyajian materi mengenai Swamedikasi terkait penggunaan obat saat puasa, diskusi dan tanya jawab.

\section{HASIL DAN PEMBAHASAN}

\section{Swamedikasi Pada Pengobatan Pasien}

Swamedikasi harus dilakukan sesuai dengan penyakit ringan yang dialami. Kesalahan penggunaan obat dalam swamedikasi ternyata masih sering terjadi seperti pada faktor ketidaktepatan obat dan dosis obat yang dapat menimbulkan risiko pada kesehatan pasien. Upaya penanggulangaan untuk mengurangi dan mencegah terjadinya masalah yang berhubungan pada kesehatan pasien salah satunya dapat diberikan dengan edukasi Kesehatan khususnya yang diberikan seorang apoteker. Edukasi tersebut perlu dilakukan dan dijadikan kebiaasan dalam dunia kesehatan. Apoteker dengan kewenangan dan kualifikasinya dapat membantu pasien memilihkan pengobatan secara baik dan benar. Salah salah satu bentuk pemberian edukasi farmasi yang diberikan apoteker berupa penyuluhan tentang pengetahun dan pemahaman pasien atau masyarakat pada umumnya tentang penyakit-penyakit yang dapat diobati sendiri dan bagaimana cara mengobati permasalahan pasien dalam penggunaan obat. 
Permasalahan pasien terutana yang berhubungan pada penyakit yang diderita pasien seringkali dianggap sebagai penyakit biasa. Pasien masih banyak yang belum mengetahui bagaimana cara mengobati permasalahan penyakitnya dengan baik, aman, dan efektif sesuai dengan tujuan terapi. sehingga dalam penggunaan dan pemilihan obat yang digunakan selama ini dilakukan tidak secara tepat dan benar. Dampak serius akibat kesalahan pada penggunaan obat yang salah dapat menyebabkan kecacatan dan penurunan kualitas hidup. Kebiasaan yang sering terjadi dan dilakukan masyarakat adalah langsung minum obat ketika mengalami sakit tanpa berkonsultasi kepada petugas kesehatan. Berdasarkan hal tersebut pengobatan sendiri (swamedikasi) harus dilakukan dengan pemantauan apoteker selaku orang yang berwenang terhadap obat.

\section{Peranan Apoteker pada Swamedikasi Pasien BPJS}

Jaminan kesehatan secara nasional yang telah berlaku saat ini merupakan salah satu upaya untuk memberikan rasa aman kepada pasien agar senantiasa mendapatkan pelayanan maksimal seperti pada pelayanan yang bersifat promotif, prefentif, kuratif dan rehabilitatif dengan biaya yang terjangkau. Biaya kesehatan di Indonesia yang tergolong mahal sebagian diantaranya telah dapat diatasi dengan adanya jaminan kesehatan seperti BPJS. Salah satu peran tenaga kesehatan seperti apoteker adalah untuk menjamin bahwa pasien menerima obat dan pengobatan dengan baik, aman, dan efektif sesuai dengan tujuan terapi. Upaya lainnya seperti memberikan edukasi dalam bentuk penyuluhan berupa pendidikan kesehatan.

Peran apoteker tidak dapat dipisahkan dari program Badan Penyelenggara Jaminan Sosial (BPJS) karena apoteker berada dalam seluruh rantai pendukung Jaminan Kesehatan Nasional (JKN). Era BPJS yang terjadi saat ini berupaya untuk tetap menjaga fungsinya dengan baik karenanya diharapkan apoteker dapat semakin bekerja profesional, 
apoteker diharapkan secara rutin melakukan peninjauan kembali pada semua institusi penyedia pelayanan kefarmasian serta menilai kelayakan produk kefarmasian yang digunakan masyarakat.

Tujuan dari penyuluhan pendidikan kesehatan adalah untuk mengubah pengetahuan \& kebiasaan masyarakat dengan berperan aktif untuk meningkatkan kesehatan yang optimal. Apoteker sebagai salah satu tenaga kesehatan mempunyai peranan sangat penting dalam pencegahan terhadap kesalahpahaman masyarakat tentang penggunaan obat pada pengobatan sendiri. Pemberian materi dilakukan dua kali, Pelaksanaan penyuluhan kesehatan diawali dengan pemberian materi mengenai swamedikasi secara umum.

Pelaksanaan awal penyuluhan diberikan materi untuk dapat menggali informasi dari peserta kegiatan pengabdian mengenai pengetahuan mereka tentang pengobatan penyakit yang dapat diobati dengan swamedikasi. Penyuluhan materi kedua diberikan untuk melihat bagaimana respon dari pemberian materi awal yang telah disampaikan ditambah dengan materi terkait swamedikasi pada penggunaan obat saat pasien melakukan puasa. Setelah pemberian materi selesai diberikan didapatkan hasil bahwa pasien BPJS sebagai peserta kegiatan telah dapat menambah pengetahuannya terkait swamedikasi.

Program penyuluhan ini dapat menumbuhkan kesadaran masyarakat selaku pasien BPJS untuk lebih perhatian terhadap kesehatan. Antusiasme masyarakat dalam bertanya menunjukkan keberhasilan dalam pencapaian tujuan kegiatan ini. Sehingga apa saja yang diharapkan mengenai hasil kegiatan ini dapat tercapai dengan baik. 

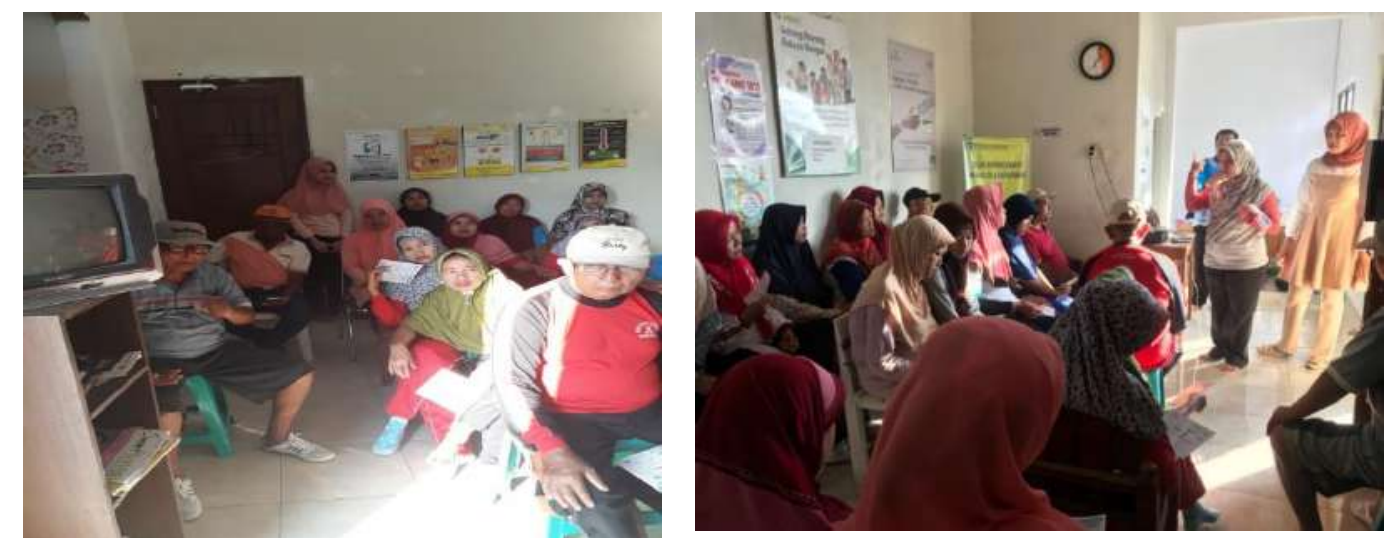

Gambar 1. Penyuluhan Peran Apoteker dalam Pemberian

Swamedikasi pada Pasien BPJS

\section{SIMPULAN DAN SARAN}

\section{Simpulan}

Peran Apoteker dalam Pemberian Swamedikasi pada Pasien BPJS yang dilakukan telah sesuai target yang diharapkan. Target yang dicapai berupa menghasilkan luaran yang dapat membentuk pola pikir dan cara pandang masyarakat untuk dapat menyikapi secara tepat tentang penggunaan obat terkait pengobatan yang dapat diobati sendiri oleh pasien tanpa konsultasi dengan dokter dimana peran serta apoteker dilakukan dengan memberikan penyuluhan kesehatan terkait penyakit yang dapat diobati sendiri oleh pasien, cara mendapatkan dan penggunaan obat yang baik dan benar.

\section{Saran}

Perlu diadakan penyuluhan kesehatan dengan topik yang berbeda untuk meningkatkan pengetahuan masyarakat.

\section{UCAPAN TERIMAKASIH}

1. Program Pengabdian masyarakat ini dibiayai oleh STIKES Cendekia Utama Kudus dengan Surat Perjanjian Kontrak Pengabdian Masyarakat (SPK-PM) Nomor: 023/SK-PI/LPPM-STIKES CU/V/2018 
2. Fasilitas Kesehatan Tingkat I dr. Arief Adi Saputro yang telah memberikan ijin sehingga program pengabdian masyarakat ini berjalan dengan baik

\section{DAFTAR PUSTAKA}

1. Tjay, Tan Hoan Rahardja. (2010). Obat-obat Penting. PT. Elex Media Komputindo.Jakarta

2. Departemen Kesehatan RI. 1993. Permenkes No.919/MENKES/PER/X/1993. Jakarta

3. Sriana A. (2004). Kembali Sehat dengan Obat. Pustaka Populer Obor,Jakarta

4. Depkes, (2008). Materi Pelatihan Pengetahuan dan Keterampilan Memilih Obat BagiTenaga Kesehatan, Departemen Kesehatan RI, Jakarta. 